\title{
Chemical Examination Of Sandbox (Hura Crepitans) Seed: Proximate, Elemental And Fatty Acid Profile.

\author{
OYELEKE, G.O. ${ }^{1}$, OLAYIWOLA, O.A. ${ }^{2}$ and LATONA, D.F. ${ }^{2}$ \\ ${ }^{1}$ Science Laboratory Technology Department, Osun State Polytechnic, Iree, Nigeria \\ ${ }^{2}$ Applied Sciences Department, Osun State Polytechnic, Iree,
}

Nigeria.

\begin{abstract}
A study in terms of proximate, elemental and fatty acid contents of (Hura crepitans) seed was investigated using standard analytical techniques. The results of proximate composition in \% were as follows: moisture $12.82 \pm 0.01$, crude protein $24.76 \pm 0.04$, crude fibre $10.15 \pm 0.03$, fat $10.68 \pm 0.01$, ash $3.16 \pm 0.02$ and carbohydrate $34.75 \pm 0.05$. The elemental composition of the seed showed $\mathrm{Na}, \mathrm{K}, \mathrm{Ca}$ and $\mathrm{Mg}$ in $\mathrm{mg} / \mathrm{loOg}$ to be $6.00 \pm 0.01,123.00 \pm 0.02,10.40 \pm 0.03,112.00 \pm 0.01$ respectively while other elements determined in $\mathrm{mg} / \mathrm{kg}$ were Fe and $\mathrm{Zn}$ with $7.10 \pm 0.04$ and $2.60 \pm 0.01$. The (\%) free fatty acid compositions of the seed oil were as follows: lauric (1.310 \pm 0.015$)$, palmitic $(0.389 \pm 0.012)$, palmitoleic $(1.211 \pm 0.013)$, stearic $(2.436 \pm 0.004)$, oleic $(6.138 \pm 0.003)$, linoleic $(8.625 \pm 0.001)$ and linolenic $(2.469 \pm 0.102)$. The results revealed linoleic and oleic acids to be the most common in terms of abundance while palmitic acid was the least. The seed of Hura crepitans could be described as a good food because it contained significant amount of essential nutrients required by man.
\end{abstract}

Keywords: Proximate, elemental, fatty acid, Hura crepitans, seed-oil.

\section{Introduction}

Seeds form an important part of the diet of human beings and are usually regarded as food. Seeds are good sources of edible oils and fats. They are potential raw material for local industries. Most foods especially in Africa including Nigeria consist mostly of staple carbohydrate foods which provide only calories and therefore are nutritionally poor in quantity and quality which results in problem of malnutrition. The discovery of new sources of plant proteins from seeds will help to supplement the nutrients of staple carbohydrate foods. The ultimate success of utilizing plant proteins as food ingredients largely depends upon the beneficial qualities they impact to food which in turn depend on their nutritional and functional properties [1]. The biological significance of naturally occurring fatty acids revealed that they are necessary for animal metabolism and storage of energy. A great majority of fatty acids were in the form of triglycerides. Dietary fatty acids influence the utilization and metabolism of carbohydrates, proteins, minerals and vitamins [2]. Fatty acids also influenced and improved immune and humeral responses. Sandbox (Hura crepitans) seed is an evergreen tree of Euphobiaceae family that despite it abundance in Nigeria it is still been under- utilized. It is recognized by many dark pointed spines and smooth brown bark, these spines have caused it to be called monkey no climb [3]. The bark of sandbox tree is an herbal medicine for human and veterinary. The purpose of this study is to investigate further on the proximate, elemental as well as fatty acids profile of sandbox (Hura crepitans) seed in order to give adequate information on it suitability for consumption.

\section{Materials and methods}

\subsection{Sampling and Sample Treatment}

Dried sandbox (Hura crepitans) seeds were collected at the back of Administrative block, Osun State Polytechnic, Iree, Boripe local government area, Nigeria. It was identified at the herbarium unit, Botany department of Obafemi Awolowo University (O.A.U), Ile-Ife, Osun State, Nigeria. The pods were cut open and the seeds removed and sun dried for two (2) weeks after which the seeds were decorticated, grinded and passed through a $2 \mathrm{~mm}$ sieve. It was then stored in a polythene bag for further study.

\subsection{Methods}

\subsubsection{Proximate Analysis}

The recommended methods of AOAC [4] were used for the determination of moisture, ash, crude fibre and crude protein contents while carbohydrate was calculated by difference by subtracting total sum of crude protein, crude fibre, crude lipid, moisture and ash from 100\% dry weight sample. 


\subsubsection{Minerals}

Mineral elements including zinc, iron, magnesium, calcium were determined by atomic absorption spectrophotometry while sodium and potassium were determined using flame photometry.

\subsubsection{Fatty Acid Composition}

Fatty acid composition was determined according to the methods of Metcalfe and Schmitz as described by Mohammed, [5].

\section{Results and Discussion}

TABLE 1: Proximate composition of Hura crepitans seed (\%)

\begin{tabular}{lc}
\hline Sample & value \pm S.D \\
\hline Moisture & $8.02 \pm 0.01$ \\
Fat & $23.52 \pm 0.01$ \\
Ash & $3.54 \pm 0.02$ \\
Crude protein & $25.76 \pm 0.04$ \\
Crude fibre & $7.65 \pm 0.03$ \\
Carbohydrate & $38.75 \pm 0.05$ \\
\hline
\end{tabular}

Results are average of duplicate determination \pm S.D

TABLE 2: Fatty acid composition of the seed (\%)

\begin{tabular}{lc}
\hline Parameters & Value $\pm \underline{\text { S.D }}$ \\
Linoleic acid (C18:2) & $8.265 \pm 0.001$ \\
Oleic acid (C18: 1) & $6.138 \pm 0.003$ \\
Linolenic acid (C18:3) & $2.469 \pm 0.102$ \\
Stearic acid (C18:0) & $2.436 \pm 0.004$ \\
Lauric acid (C12:0) & $1.310 \pm 0.015$ \\
Palmitoleic (C16:1) & $1.211 \pm 0.013$ \\
Palmitic acid (C16:0) & $0.389 \pm 0.012$ \\
\hline \multicolumn{1}{c}{ Results are average of duplicate determination \pm S.D }
\end{tabular}

Table 3: Elemental composition of Hura crepitans seed.

\begin{tabular}{|c|c|}
\hline Element & Value \pm S.D \\
\hline Sodium $(\mathrm{Na})^{n}$ & $\overline{6.00 \pm 0.01}$ \\
\hline Potassium $(\mathrm{K})^{*}$ & $123.00 \pm 0.02$ \\
\hline Calcium $(\mathrm{Ca})^{*}$ & $10.40+0.03$ \\
\hline Magnesium $(\mathrm{Mg})^{*}$ & $112.00 \pm 0.01$ \\
\hline $\operatorname{Iron}(\mathrm{Fe})^{* *}$ & $7.10 \pm 0.04$ \\
\hline $\operatorname{Zinc}(\mathrm{Zn})^{* *}$ & $2.60 \pm 0.03$ \\
\hline
\end{tabular}

\section{Discussion}

Table1 showed the results of the proximate composition of Hura crepitans seed and the parameters analyzed include the moisture content which was found to be (12.82 \pm 0.01$)$, this value is in line with $11.07 \%$ [6] but lower than $14.3 \%$ [7] reported for soybeans and coconut seeds respectively. This value is however higher than the values for palm kernel (5.31\%) and cotton seeds (6.46\%) [6]. The percentage moisture content of the seeds from the analysis is higher than $3.00 \pm 0.13 \%$ [8] for Hibiscus sabdariffa seed. The percentage moisture content of this seed is a little bit higher than $10 \%$ of total weight required for proper storage to prevent microbial growth. 
The fat content of the seed was found to be $23.52 \pm 0.01$. This value is lower than $37.78 \%$ reported for the Hura crepitans seed [9]. The fat content of the seed was within the range of $9-34 \%$ reported for cucurbit seeds from Niger republic by other researchers elsewhere. The fat content was however found to be higher than $6.73 \%$ [10] for Mucuna pruriens and $2.31 \pm 0.04 \%$ [8]. The ash content of Hura crepitans seed was found to be $3.54 \pm 0.02 \%$ which was lower than $4.34 \pm 0.04 \%$ [11] reported for Telfairia occidentalis and higher than $2.8 \%$ reported for Anarcadium occidentalis by Akinhanmi et al, [12], this value was however close to 3.14\% reported for the sample by Fowomola and Akindahunsi, [13]. The crude protein content of the seed was found to be $25.76 \pm 0.04 \%$ and is lower than $39.25 \pm 0.66 \%$ reported for pumpkin seed [5], this value was higher than $21.0 \%$ reported by Kuzayi et al, [14] for Lebanese cultivars of sesame seed. The value is comparable to $25.16 \pm 0.22 \%$ [13] for the seed. The amount of protein in the sample makes it nutritiously rich and contributes to the daily protein need of $33.6 \mathrm{~g}$ for human adults [15]. The high crude protein content of the Hura crepitans seed suggest it to be a good source of protein which is useful in the normal building up and repaired worn out tissue.

The fibre content was found to be $7.65 \pm 0.03$ in the sample. It is higher than $5.30 \%$ reported by Afolabi et al, [16] for Mucuna solanei. This high content in crude fibre suggests the suitability of compounding it in animal feed because it is a good source of purgative [17]. It enhances digestibility, decreases the blood cholesterol and reduces the risk of large bowel cancer.

Table 2 showed the fatty acid profile of Hura crepitans seeds. The result (\%) of both oleic and linoleic acids from the results were found to be $6.138 \pm 0.003$ and $8.265 \pm 0.001$ respectively which revealed that the two fatty acids were the most abundant fatty acids in the sample. This order was reported to be the case with most plant seed oils [18]. Lauric and palmitoleic acids were found in low but measurable quantities in the sample. The lauric acid content of the seed was $1.31 \%$, which was higher than the $(0.03 \%)$ reported for Mucuna puriens var. utilis (white) by Mohan and Janardhanan [19]. Stearic and linolenic acids were found to have comparable values of $2.44 \%$ and $2.47 \%$ respectively.

Fatty acids serve as the building blocks of fat in the body and in food and are source of energy as well as constituents of cellular membranes. The lauric acid is found in the human breast milk and plays important roles in nourishing and protecting babies from various infections. Linoleic and linolenic acids are unsaturated fatty acids and their deficiencies can cause loss of hair, susceptibility to infection, poor wound heal and circulatory problem.

Table 3 showed the elemental composition of the seed in $(\mathrm{mg} / 100 \mathrm{~g})$. Potassium $(\mathrm{K})$ was found to be the most abundant element with $123 \mathrm{mg} / 100 \mathrm{~g}$ and $\mathrm{Zinc}(\mathrm{Zn})$ the least abundant element with $2.6 \mathrm{mg} / 100 \mathrm{~g}$ in the seed. The sodium $(\mathrm{Na})$ and the magnesium $(\mathrm{Mg})$ content were found to be $6 \mathrm{mg} / 100 \mathrm{~g}$ and $112 \mathrm{mg} / 100 \mathrm{~g}$ respectively. These elements are important in maintaining electrical potential of nervous system and also in normal functioning of muscle and nerves tissue. The value of magnesium in these samples is lower than $350 \mathrm{mg} /$ day recommended daily allowance (RDA) [20]. The calcium (Ca) content of $10.4 \mathrm{mg} / 100 \mathrm{~g}$ in $\mathrm{Hura}$ crepitans seed was lower than $12.80 \mathrm{mg} / 100 \mathrm{~g}$ reported for the seed by Ezeagu et al, [21]. It was also lower than the $300 \mathrm{mg}$ recommended daily allowance [20] and therefore would need to be supplemented. Iron (Fe) content of $7.1 \mathrm{mg} / 100 \mathrm{~g}$ is higher than $5.19 \mathrm{mg} / 100 \mathrm{~g}$ obtained by Rajaram and Janardhanan [22] for Mucuna pruriens. The iron needs to be supplemented from other source in order to be adequate enough to accommodate the limit advised for animal nutrition. The mineral compositions showed the seed to be fairly good source of calcium, potassium, sodium and magnesium.

\section{Conclusion}

The proximate composition showed that the seed contained appreciable quantity of useful substances (crude protein, fat, ash and carbohydrate) with crude fibre which is desirable in digestibility, decrease in blood cholesterol and reduces the risk of large bowel cancer. The minerals and the fatty acid profile were also significant. The seed could therefore be used as one of the underutilize food source to solve the problem of mal-nutrition associated with food (balanced diet) among developing and under developed countries of the world.

\section{Recommendation}

It is recommended that further work should be carried out on functional properties, antinutrients and heavy metals composition of the seed in order to place it appropriately on the food table. 


\section{References}

[1] O. A. Afolabi, B. A. Oshuntogun, S. R. Adewusi, O. O. Fapojuwo, F.O. Ayorinde, F. E. Grisson and O. L. Oke, Preliminary nutritional and chemical evaluation of raw seeds from Mucuna solanei. An underutilized food sources, J. Agric. Food chem., 33, (1984), 122-124.

[2] K. Ajewole and A. Adeyeye, Seed Oil of White Star Apple (chrysophyllum albidum) Physico-chemical characteristics and fatty acid composition, J. Sci. Food Agric., 54, 1992, 313-315.

[3] T. F. Akinhanmi, V. N. Atasie and P. O. Akintokun, Chemical composition and physico-chemical properties of cashew nut (Anarcadium occidentale) Oil and cashew nut shell liquid, J. Agric. Food \& Env. Sci., Vol. 2, 2008, 1 - 9.

[4] AOAC, Official method of analytical chemist. $17^{\text {th }}$ Edition, (2000), Washington, D.C.

[5] H. M. Burkill, The useful plant of West tropical Africa, Vol., 2, 1994, 84-85.

[6] I. E. Ezeagu, B. Maziya- Dixon and Tarawali, Seed characteristics and nutrient and anti-nutrient composition of 12 Mucuna accessions from Nigeria, Trop. \& Subtrop. Agro Ecosys.1, 2003, 129-140.

[7] FAO, Food composition table for the Near East nut and seeds. FAO food and nutrition paper, 26, $1982,85$.

[8] M. A. Fowomola, and A. A. Akindahusi, (2007). Nutritional quality of sand box tree (Hura crepitans linn), J. Med.food. Vol., 10(1), 2007, 159-164.

[9] S. J. Kershaw and F. Hackett, Comparison of the three standard solvent extraction procedures for the determination of oil content in commercial oil seed sample, J. Sci. Food Agric. 40(3), 1987, 233-244.

[10] M. V. Kuzayi, J. W. Cowan and Z. I. Sabry, Nutritive value middle eastern food stuffs II. composition of pulses, seed, nut, and cereal product of Lebanon, J. Sci. Food Agric. 17, 1996, 82-84.

[11] V. R. Mohan and K. Janardhanan, K. (1995). Chemical analysis and nutritional assessment of lesser known pulses of the genus Mucuna species, Adv. Plant Sci. 6, 1995, 344-350.

[12] A. A. Mohammed, Chemical composition and oil characteristic of pumpkin (Cucurbita maxima) seed kernels, Res. Bult. No (129), 2004, 5-18.

[13] National Research Council (NRC), Recommended daily dietary allowance, Nutritional Review 31(12), 1974, 373-395.

[14] R. A. Oderinde, I. A. Ajayi, F. A. Dawodu and K. O. Adebowale, Chemical composition of Pentaclethra macrophylla seed and seed oil grown in Nigeria, Riv. Ital. Sostanze Grasse. 74;2003, 183-185.

[15] G. O. Oyeleke, Evaluation of nutrient and anti-nutrient composition of Hibiscus sabdariffa seed flours, Int. J. Food sci. \& Tech., 1 (1), 2009, 31-35.

[16] G. O. Oyeleke and E. O. Olagunju, Studies on Cucurbita maxima and Telfairia occidentalis (seed and seed Oil), J. New Trends Sci. \& Tech. Appl. Vol., 1, 2011, 43-55.

[17] N. Rajaram and K. Janardhanan, The Biochemical composition and nutritional potential of the Tribal pulse Mucuna gigantea Wild DC, Plant Food for Hum. Nutr. 41: 1991, 45-52.

[18] P. Siddhuraju, K. Vijayakumari and K. Janadhanan, Chemical composition and protein quality of the little-known legume velvet beans (Mucuna pruriens) DC, J. Agric. Food Chem., 44, 1990, 2636-2641.

[19] O. A. Shadrach, and G. L. Oyebiodun, The functional characteristics of starch from cowpea, pigeon pea and yam bean, Food Chem. 65: 1999, 460-474.

[20] S. Shameel, K. Usmanghani, M. Shaiq Ali and V. Ahmad, Caesalpinia bonduc (L) Roxb seed oil: lipid composition assessment, Pak. J. Pharm. Sci. Vol 10: 1997, 29-38.

[21] R. D. A. Thangadurai, M. B. Viswanathan and N. Ramesh, (2001). Nutritional potential of biochemical components in Galactia longifolia Benth, Nahrung/Food".45(2), 2001, 97-100.

[22] G. Vogg, E. Mattes, J. Rothenburger, N. Hertkom, S. Achatz and H. Sandermann, Tumor promoting diterpenes from E. leuconeura L, Phytochem. 51: 1999, 289-292. 